\title{
The Counterrevolution Is Not Over: Commemorating Legh Richmond
}

The Rise IN Stature of THE evangelical writer Hannah More in romantic studies has been accompanied by the kind of editing and publishing associated with a minor figure: hardcover volumes destined for research libraries, and a more limited presence in teaching anthologies and paperback editions. ${ }^{1}$ Meanwhile, though, another recovery operation has been underway outside the university, as enterprising American evangelical publishers have brought out inexpensive paperback and online editions of her work, so that Practical Piety (1811) can be read at the "Grace Books" department of gracegems.org, and Tom White the Postboy (1795) and The Two Wealthy Farmers (1795-97) are available from Grace and Truth Books of Sand Springs, Oklahoma. ${ }^{2}$ The Grace and Truth editions are sturdy paperbacks, costing less than ten dollars, though they are indifferently edited: with texts and images drawn from early nineteenth-century American sources, they sound a distant echo of the Second Great Awakening. The volume The Two Wealthy Farmers includes other Cheap Repository material, indicating that the contents were "originally published by The American Tract Society of New York," but the publisher seems unconcerned about earlier transatlantic origins. ${ }^{3}$ These editions have made their way out from Grace and Truth to a number of online Christian retailers, so that More can now be found in the "Religious Stories" department of the "Radio Bible \& Book Room" and the "Preferred Booklist" of Utmost Enterprises. ${ }^{4}$ Here she joins a wealth of material targeting a home-schooling movement that has become a bastion of the Christian right in the United States. ${ }^{5}$

Now it is easy to interrogate skeptically the misplaced nostalgia that finds twenty-first-century American evangelical publishers discovering neglected moral standards in a version of late eighteenth-century English rural society

\footnotetext{
A B S T R A C T Recent critical interest in romantic-period evangelical literature has been shadowed by another recovery project outside the university, as American evangelical publishers have brought out devotional editions of the religious works of Hannah More and Legh Richmond written in the late eighteenth and early nineteenth centuries. While it is easy to dismiss this as cultural nostalgia, contemporary Christian publishers are alert to the enterprising and activist character of early evangelical tract literature. If there is a lapse of historicism about their recovery project, there is also another way of thinking about history and human agency. RePresentations 114. Spring 2011 (c) The Regents of the University of California. ISSN 0734-6018, electronic ISSN 1533-855X, pages 129-56. All rights reserved. Direct requests for permission to photocopy or reproduce article content to the University of California Press at http://www.ucpressjournals.com/reprintinfo.asp. DOI:10.1525/rep.2011.114.1.129.
} 
that never really was-its deferential servants and precociously devout children existing only as artifacts of Hannah More's campaign to market reassuring figures of subordination to nervous elites and middle-class moral entrepreneurs like herself. Are contemporary American readers expected to approve More's commitment to monarchy and landed privilege and her contempt for popular right, ritually enacted in the antidemocratic conversational formula by which ordinary shoemakers and coachmen willingly leave political affairs to their superiors? It is not enough to grant the conservative target audience for these reprinted tracts. Historians have long recognized that American fundamentalism, more than its counterparts elsewhere, has been distinctively shaped by the American Enlightenment, resulting in a greater openness to republican ideology. ${ }^{6}$ And, politics aside, what should contemporary American readers make of the sheer barrage of particular social circumstances-having to do with class structure, market relations, property rights, parish relief, village ritual, and so on-through which More argues the stakes of her moral reform project, and coordinates her fiction with the wider framework of a government and social hierarchy coming to terms with popular discontent in the protracted crisis of the 1790s?

Yet a critical account of the present American evangelical recovery of Hannah More must acknowledge that these modest paperback editions are more consistent with her designs than would be any amount of scholarly editing, and they sustain a tradition in the American book trade reaching back to the New York, New England, and Philadelphia missionary tract societies of the early nineteenth century, which themselves drew heavily on British sources and introduced readers along the Eastern Seaboard to the Cheap Repository tracts. ${ }^{7}$ The cosmopolitan scope of this early evangelical print culture registers powerful antisecular and even counter-Enlightenment strains in American society, suggesting that recent developments on the Christian right are evidence of enduring contradictions rather than the betrayal of some fabled republican experiment. Like More's Cheap Repository, the work of these twenty-first century publishers and distributors is closely coordinated with a program of educational reform, as Christian home-schoolers pursue a broad challenge to the monopoly of secular public schools on state and federal education funding. Considered alongside the other printed material in these catalogs-Christian-themed early readers; scripturally based self-help literature; devotional calendars and diaries; mystery, adventure, and historical fiction series-the resurrected Cheap Repository tracts figure in a campaign, reminiscent of More's own, to displace available popular literature and provide an entire course of pious reading. Even the casualness about matters of text and authorship recalls a similar heterogeneity in the London, Bath, and Dublin tracts of the 1790s, which often reshuffled material from the Cheap Repository's initial monthly series. 
And the movement of a tale like Tom White out from nineteenth-century American missionary sources to a range of online booksellers can enrich and complicate some of our usual categories for reception history. In More's time and in our own, evangelical reception involves above all the reproduction and transmission of specific devotional conditions for literary reproduction and transmission. These texts are insistently framed, within and without, by the discipline of pious reading habits and by educational methods calculated to extend the process of Christian conversion.

Another leading romantic-period tractarian and early secretary to the London Religious Tract Society, the Reverend Legh Richmond, appears alongside Hannah More in the catalogs of Grace and Truth Books and related online booksellers. ${ }^{8}$ Here American evangelicals may be working in advance of university scholarship. There are a few accounts of Richmond's work in romantic studies, including an article by Gary Kelly and a discussion in Roger Sales's book on pastoral, but as yet no print editions or anthologies that include his writing. ${ }^{9}$ Instead, something like the dual lines of Hannah More's recuperation (academic, devotional) can be traced through online publishing. With funding from the National Endowment for the Humanities, the University of North Carolina's "Documenting the American South" project has mounted an electronic edition of Richmond's narrative tract The Negro Servant, confirming the importance of transatlantic transmission. ${ }^{10}$ Versions of The Dairyman's Daughter can be found in Agape Chapel Ministry's online "Sound Doctrine" library, and alongside buttermilk biscuit recipes and modest swimwear catalogs in the e-book department of the website Being Virtuous Women. ${ }^{11}$

While much of the online evangelical marketing I have cited so far is technically unsophisticated, Being Virtuous Women is a more impressive piece of digital work, elaborately networked and elegantly mounted on Moveable Type software by its hostess, Amber Moeller, a self-described "home-school graduate who lives quietly with her parents . . . in a small farming community in the heartland of Illinois," and who conducts a related family blog at the online community HomeschoolBlogger.com. ${ }^{12}$ For this reason, Being Virtuous Women renders particularly visible some characteristic paradoxes about the way intensely countermodern sensibilities (sharp reactionary notes are struck in defense of scriptural patriarchy, and in links to Ladies Against Feminism) have come to be organized in a digital Christian community that extends outward from a virtual home in America's Bible Belt to national evangelical organizations and international missions. ${ }^{13}$ Nostalgia is easily found. Moeller's taste in clothing and domestic handicraft is suffused with colonial and Victorian Americana. A homemaking department comes under the figure of the "Handbasket," recalling "the days of hoop-skirts and bustles" when such baskets were useful conveyances ("to carry midwifery supplies, handiwork, picnic lunches") 
and had the further devotional purpose of keeping female hands busy. "Many young ladies were admonished by their mothers with the words: 'Idle hands are the devil's playground." "14 There is a backward glance as well in the site's derivation of its founding conception of virtue and "godly womanhood" from Noah Webster's 1828 dictionary. ${ }^{15}$

Yet the scriptural rhythms and evangelical jargon of Moeller's prose are as countercultural and otherworldly as they are anachronistic, a case of the "exclusionary communication behaviors" that Robert Glenn Howard has described in the online vernacular of Christian fundamentalism. ${ }^{16}$ This is evident in Moeller's declaration that "her greatest desires (other than striving to be more Christ-like with each passing day) are to be a wife, a mother, and a joyful keeper-at-home. But until that time, she remains a contented maiden who delights in the covering (headship) of her father." cal explanation and scriptural support are provided for the concept of the "covering" father and husband. ${ }^{18}$ Given the resonance throughout the site of figures of protected femininity and enclosed domesticity, there is a palpable tension about the potentially unguarded opening of Being Virtuous Women to a virtual community of unknown visitors, through the public work of a young woman who wants nothing more than to pass from the protection of a father to that of a husband, and who explains that she did not attend college because "pursuing a life outside of the home" undermines "contented maidenhood" by "stealing our hearts away from our God-given role of being keepers at home." 19 In this sense, one of the most revealing features of Being Virtuous Women is its privacy policy, which offers the usual assurance about the personal information of visitors, but adds a stipulation about the modesty and submission of its female mistress: "This site is run by a sister-inChrist-under the over-sight of her father."20

Even allowing this emphasis on confined Christian femininity, the life figured on Being Virtuous Women is not wholly separatist or unworldly. Moeller's collection of "Favorite Links" range from specifically Christian marketers such as Swim Modest and Modest Handmaidens Mercantile to the mainstream commercial websites of Hallmark, Martha Stewart, and the Wedding Channel. ${ }^{21}$ Recommendations in the "Bookworm Corner" extend from Legh Richmond and other Christian evangelical literature to Jane Austen, James Fenimore Cooper, and H. Rider Haggard, with links to university electronic editions. ${ }^{22}$ Moeller is often calculated and even playful in configuring the digital with the archaic, as in the "Quill Pen-FAQ" department of visitor questions ${ }^{23}$ In this sense the apparent paradox of a technologically sophisticated female evangelical expression bears out longstanding historical tensions in American evangelicalism between separatist impulses and a fuller engagement with mainstream society and politics, tensions that have animated rather than disabled evangelical culture. ${ }^{24}$ 
Where fundamentalism as the paradigmatic form of "militantly anti-modernist Protestant evangelicalism" was born in the United States in the 1920s of a struggle against theological modernism and evolutionary theory, in a form that tended (particularly in defeat) toward separatism, the broader pattern of conservative evangelical religion has been more complicated and ambivalent in its relation to modernity. ${ }^{25}$ Recent theoretical interest in global fundamentalism alerts us to the broader significance of this issue. Carla Pasquinelli has observed how the usual tendency to treat Protestant fundamentalism "as an anti-modern reaction" has broken down in a comparative perspective, so that the whole range of fundamentalisms, "though deeply rooted in religion and bearing anti-modernist ideology and symbols, ... must be inscribed-albeit in a contradictory fashion-in the area of modernity. ${ }^{, 6}$ Pasquinelli develops the point theoretically, "given that all rejections imply the acknowledgment of and a relationship to what is refused," and then returns through the Islamic case to an argument against "a simplistic binary opposition between archaic and modern," and to an arresting conception of the underlying historical "ambiguity of fundamentalism." She is particularly interested in the challenge that Islamic fundamentalism poses to dominant Western historical paradigms: "This is what fundamentalism fights against, the notion that there is only one way to modernity. The sense one gets from fundamentalist writings is that their opposition to modernity is expressed in terms of an alternative rather than an outright negation." ${ }^{27}$

American experience indicates a version of her case within the West. "The old-time religion has always been changing, innovative, and in many ways up to date." ${ }^{28}$ Histories of the nineteenth-century revivalism that spawned the paradigmatic fundamentalism of the 1920s, and of the more loosely construed contemporary "fundamentalistic evangelicalism" that followed in its wake, have used such terms as ambiguity, paradox, and symbiosis to describe the relation between evangelical Protestantism and modernity. ${ }^{29}$ Amber Moeller and other recent "pilgrims in cyberspace" follow a long twentiethcentury tradition in which conservative Protestant evangelicals took the lead in engaging commercial society and adapting new technologies, from the pioneers of evangelical radio in the 1920s through the television ministries of the 1970s. ${ }^{30}$ In defining the relationship between American Protestant evangelicalism and modernity, historians have developed formulations that accord strikingly with Pasquinelli's, though with a greater emphasis on accommodation. Thus Martin Marty defines evangelicalism as "the characteristic Protestant . . way of relating to modernity," and Joel A. Carpenter urges that "rather than viewing evangelicalism as a throwback, as a religion of consolation for those who cannot accept the dominant humanist, modernist, liberal, and secular thrust of mainstream society," we should understand it "as a religious persuasion that has repeatedly adapted to the changing tone and rhythms 
of modernity." ${ }^{31}$ Carpenter pursues his case back through the evangelical revivals of the eighteenth century, and the transatlantic careers of George Whitefield and John Wesley. In this way he reveals historical patterns that help explain the appeal of activist, revisionist moral entrepreneurs like Richmond and More to a contemporary American evangelical movement that is at once self-consciously nostalgic and aggressively engaged in the social and commercial networks of modernity. ${ }^{32}$

Romantic-period evangelicals bear closely on this problem of the contradictory historical position of evangelicalism because, by contrast with Whitefield and Wesley, they worked in the wake of the French Revolution and the pivotal modern challenge of an irreligious revolutionary Jacobinism, which sharpened the terms in which Christian activists challenged and accommodated modernity. Boyd Hilton has observed that the nineteenth-century mobilization of evangelical piety for moral and social improvement was triggered by "an upper- and middle-class reaction against the French Revolution and English Jacobinism." 33 Indeed, the tensions that animate a technologically sophisticated American evangelical conservatism recapitulate founding tensions within modern conservatism that can be traced back to the late-Enlightenment and romantic period, and that are too often overlooked when we take reactionary movements at their own retrospective valuation. Like evangelical piety, the conservative structures of feeling that emerged in the era of the American and French Revolutions were at once features of modernity and reactions to it, and cannot simply be assigned to residual social forms. In his study of the counter-Enlightenment in France, Darrin McMahon makes the point vividly when he describes how the "new ideological culture" of the Right took shape within the emerging institutions of the political public sphere:

[The Right's] defense of tradition was not traditional, its reverence for history was a historical departure, and its arguments for the family and patriarchal power were a response to novel threats both real and perceived. Developing these and other innovative arguments in the face of innovative attacks, polemicists of the Right did so by direct participation in the new public sphere, also a uniquely modern product. The incipient Right detested that sphere and was convinced that the free exchange of ideas produced devastating social consequences. But . . . it was forced to adopt modern methods and modern technology, employing pamphlets, print culture, and the periodical press to compete openly in the new republic of letters. ${ }^{34}$

There are of course salient distinctions between the French and the British and American experiences in this regard, and between counter-Enlightenment and counterrevolution. I have already alluded to the distinctive American evangelical accommodation of Enlightenment republicanism, though resistance to Enlightenment secularism has remained a flashpoint for evangelical "opposition to modernizing trends" in the United States. ${ }^{35}$ And while 
the field of forces in Britain around 1800 may have been less sharply divided than what McMahon indicates for France, his underlying observations hold: about a defense of tradition that was not traditional, and about a resistance to new developments that adopted the new methods and materials of the political public sphere. Here of course evangelicals shrewdly took the lead, and Hannah More's account of the Cheap Repository captures the spirit of conservative evangelical counterengagement in print: "As an appetite for reading had ... been increasing among the inferior ranks in this country, it was judged expedient, at this critical period, to supply such wholesome aliment as might ... abate their relish for those corrupt and inflammatory publications which the consequences of the French Revolution have been so fatally pouring in upon us." 36

The distinctive persistence of evangelical strains of conservatism accounts for my title, which alludes loosely to François Furet's argument that historical analysis of the French Revolution should free itself from the sympathies and chronologies triggered by the Revolution-should accept, as he provocatively put it, that "the Revolution is over."37 In Britain and elsewhere, counterEnlightenment impulses figured prominently in the reaction to threats of revolution after 1789, as fear of Jacobin subversion released decades of pent up evangelical as well as High Church resentment about the skeptical tendencies of the long eighteenth century. In this sense, counterrevolutionary impulses were inaugurated well before the fall of the Bastille, and evangelical activism is again a particularly complex and instructive case. Joanna Innes has shown how evangelical moral reform projects of the 1770s and 1780s, which played into later counterrevolutionary movements, were born of a forward-looking determination "to create the social and institutional framework within which a more virtuous society might take shape," even as they sought to shed a "lingering taint of Puritanism and social subversion" and "make the cause of moral reform respectable" in the face of establishment critics who felt church and state bore primary responsibility for public order and virtue. ${ }^{38}$ In this sense, the counterrevolution in Britain paradoxically preceded the revolution, or at least the talismanic date 1789, and Innes suggestively invokes another revolution when she considers middle-class moral reform part of an assault on corrupt elites in the aftermath of the loss of the American colonies.

Even if we allow Furet's dictum, then, we should not be surprised to find that some strands of the counterrevolution are not over. The evangelical persistence of sharply countermodern sensibilities is evident throughout the Grace and Truth booklist. Alongside editions of More and Richmond, as well as John Bunyan and Richard Baxter, there are Christian antidotes to contemporary secular self-help literature that promise readers counseling on divorce, sexuality, addiction, learning disabilities, and eating disorders "without an ounce 
of psychology." ${ }^{39}$ If this evangelical sensibility is unappealing from a progressive perspective, it should not be overlooked. Yet critical accounts tend to consider the evangelical literary tradition a closed chapter in cultural history. A. G. Newell's 1976 doctoral study of evangelical popular prose incorporates Richmond's work into a "rise and decline" narrative, and the 1995 Blackwell Dictionary of Evangelical Biography remarks that The Dairyman's Daughter "was still in print as recently as $1972 .{ }^{40}$ While I would not claim that current American editions reverse the decline of Christian tract literature since the nineteenth century, one of my aims in the discussion of Legh Richmond that follows is to consider some of the ways in which the devotional return of romantic-period evangelical print culture can be understood in terms of its first production and narrative organization.

Further, the persistence of this literature bears with it distinctive conceptions of historical experience that have been overlooked in recent accounts of the romantic-period emergence of historicism. The oversight can be explained, and even justified, by evangelicalism's relatively impoverished sense of historical process and its tendency to consider history agonistically rather than interpretively - as the field for a struggle of good against evil, and for Christian conversion. Yet for all its analytical limitations, this outlook does convey assumptions about the structure of history and about human historical agency. And in this regard, just as new historicism has found connections with romantic historicism, so there are continuities to the evangelical conception of history. In accounting for Christian activism in Britain's "age of atonement," Boyd Hilton has cogently mapped late eighteenth- and early nineteenth-century realignments in millennial theories that coordinate evangelical patterns of expectation and activism. Where social intervention typically follows from postmillennialism, and the belief that human agency should prepare Christ's return, the early nineteenth century witnessed the emergence of a dominant form of moderate, premillenarian evangelicalism that tended to oppose social and economic programs precisely because it endorsed a "more paternalist" kind of moral intervention. According to these campaigning moralists, "God runs the material world on laissez-faire lines, in the sense that he does not often meddle with his own mechanism, and so man should not meddle either. On the other hand, the moral world does require man's intervention-hence the numerous Bible and Missionary Societies. ${ }^{" 11}$ Driven by an acutely personal sense of spiritual corruption, Christian evangelical entrepreneurs in the late eighteenth and early nineteenth centuries conceived history as field of endless human correction and amelioration, without the Jacobin prospect of utopian achievement in this world.

Hilton's account of an early Victorian society shaped by varieties of millenarianism might seem of merely antiquarian interest, except that related assumptions still condition Christian evangelical culture today. 
This is particularly true in the United States, where premillennialism has risen to the point where one of its variants, dispensationalism (which identifies divinely ordained epochs or "dispensations" in human history, each ending catastrophically), has "become diffused across general Evangelical discourse." 42 What tends to defy our own academic canons of historical analysis is precisely this persistence over time of an attitude that, whatever its precise millenarian complexion, views the human condition as an intractable "cosmic battle between the forces of good and evil." ${ }^{\text {"3 }}$ George M. Marsden has remarked that to a modern historian the fundamentalist attitude, with its emphatic supernaturalism and resistance to human development, can seem to be "not dealing with history at all." Yet he shows that it shares with other influential nineteenth-century theories of change (Darwin, Marx, geological catastrophism) an effort to understand dramatic historical transformation through patterns of sharp conflict and resolution. ${ }^{44}$ Certainly the haphazard way that American evangelical publishers reactivate miscellaneous works by More and Richmond violates critical methods that have been traced back to romantic historicism: the tendency, for example, to resist universal principles in favor of a sense that standards change over time, or the interpretive concern to date and place a text. ${ }^{45}$ Yet there is a sense in which Christian millennial theories like dispensationalism clear the space for extended phases that find human experience simply running on, as a protracted cosmic battle between good and evil, not because they ignore change but rather because they assign it to catastrophic historical ruptures and to episodes of divine judgment. The present-tense approach that Grace and Truth Books takes to the historically remote writings of More and Richmond has its counterpart in the way Richmond and his early nineteenth-century collaborators at the Religious Tract Society activated earlier devotional works by Catherine Parr, John Bunyan, and Isaac Watts. ${ }^{46}$ Of course the point is not that there has been no change in evangelical attitudes. The very process by which American dispensationalism developed out of the British Plymouth Brethren movement of the 1830s, and was then transmitted to the United States by John Nelson Darby and picked up by Dwight L. Moody and others, reveals critical changes over time in the exigencies for millennialism. ${ }^{47}$ But what is worth considering is the way Christian evangelical attitudes toward history have over time provided various rationales for experiencing the continuity between present moral and spiritual struggles and the past. If this is not in itself historicist, neither is it naively presentist nor even consistently transcendental in orientation. Certainly the case of Legh Richmond and his transmission through Britain and America reveals a vigorous commitment to the moral and social work of print in this world, and to what James Chandler (following Dominick LaCapra) terms the "worklike" or effective function of the text, itself strangely altered in an evangelical iteration. ${ }^{48}$ 
Despite critical oversight, the literary and historical significance of Legh Richmond is hard to dispute. ${ }^{49}$ Born in Liverpool in 1772 and educated at Trinity College, Cambridge, Richmond gave up early aspirations in music and medicine because of weak health, and was moved to evangelical conversion and Anglican ordination after reading William Wilberforce's Practical View of Christianity in 1797. He spent much of the next decade at a pair of curacies in the Isle of Wight, Brading and Yaverland, where he taught Sunday school and gathered the experiences that later found expression in his factually based narrative tracts. After turning down Hannah More's invitation to the curacy of Cheddar, he made his own way as a popular preacher, educator, author, and "clergyman in business," assuming the rectory of Turvey in Bedfordshire in 1805, and participating in the early history of the British and Foreign Bible Society, the Church Missionary Society, the Society for Promoting Christianity among the Jews, and the Religious Tract Society, for which he served as joint secretary from 1812 until his death in $1827 .{ }^{50}$ Founded in 1799 on the model of the Cheap Repository, the Religious Tract Society formed a crucial bridge between Hannah More's work in providing the English middle class with its first experience "in the mass production and distribution of reading matter," and the more central role that missionary and Bible societies played in the Victorian development of mass culture. ${ }^{51}$ Beginning with modest organizational resources, the society brought Anglican churchmen together with evangelical dissenters in a distinctly practical way. As R. J. Helmstadter has written, collaboration across sectarian lines was possible in part because such societies were meant to be useful rather than theologically precise: "They were conceived as pragmatically as was the Manchester Chamber of Commerce. ${ }^{\prime 52}$ The Religious Tract Society became one of the most impressively commercialized charitable publishing operations of the first half of the century, boasting an ambitious annual catalog of hundreds of narrative, historical, devotional, instructional, and doctrinal tracts. These were overwhelmingly original works commissioned by the society, with ambitious designs upon a range of audiences, achieved in part through a distinctive strategy of targeting popular taste with spiritually inflected writing on secular matters that extended from literature and science to agriculture and domestic affairs. ${ }^{53}$ There were separate tracts and series for men and women and for parents, youths, and children; for home, workplace, and schoolroom; for soldiers, farmers, and servants; for apprentices and masters; and for ministers and professionals. There were cheap formats "for Circulation by Hawkers," narrative series "adapted for Sunday Schools," handbills "suited for Gratuitous Distribution," children's books "adapted for Rewards in Sunday and other Schools," and a collection of broadsheets "Printed with Cuts, for the purpose of affixing to the Walls of Cottages, Manufactories, \&c." "54 (Printed matter as reward and interior decoration confirms an evangelical sense of 
the "worklike" text.) Benevolent income advanced to around £6,000 annually in 1850. As impressive, and what Hannah More never achieved, was the substantial income from tract sales, which reached $£ 10,000$ annually by 1825 and well over $£ 50,000$ by 1835 , so that the society was able to provide grants of support to other evangelical organizations. ${ }^{55}$

It was through this elaborate machinery that Richmond's three factually based narratives of popular conversion and devotion-The Dairyman's Daughter, The Young Cottager, and The Negro Servant, first serialized in the monthly Christian Guardian magazine from 1809, then reissued as separate tracts and collected in 1814 as Annals of the Poor-achieved their greatest impact, and became among the society's most profitable early productions. Eighty-thousand copies of The Dairyman's Daughter appeared within the first year of its tract publication in 1811 and half a million within four years; after fifty years, there were translations into more than a dozen languages and a global distribution of four million copies. ${ }^{56}$ These were, as Elizabeth Jay cautions, figures of circulation rather than readership, but they are daunting by any standard. ${ }^{57}$ Gary Kelly has identified Annals of the Poor as "the most frequently reprinted book written during the Romantic period," and he argues that it extended the reach of Anglican evangelicalism through a calculated appropriation and management of romanticism's disturbing new treatments of landscape and personal expression. ${ }^{58}$ Certainly Richmond's use of sentimental literary conventions to alleviate the rigors of evangelical devotion helps account for enduring interest in his work. Through a careful modulation of language that refines Hannah More's comprehensive yet differentiating form of address, Richmond framed and punctuated his narratives of ordinary devotion with authorial reflection and landscape meditation, weaving through his tracts instigations to middle-class provision and pastoral care as well as popular conversion. Roger Sales has identified the landscape of these tracts with a Christian pastoral that legitimates poverty and inequality by dissolving painful human experience in sentimental reflections on rural life: "The order and hierarchy of the pastoral scene is used to argue in favor of the existing social structure." ${ }^{59}$

Although More anticipated much of this when she framed and punctuated some of her own narratives with the elevated devotion of elites, the spiritual intensity of Richmond's meditations and natural prospects, along with the diminished topicality of his narratives, can seem to contrast with the mundane circumstances of the Cheap Repository. In her discussion of Richmond's favorite device of the witnessed deathbed scene, Sarah Winter discerns "a gentler Evangelical didacticism" in a spiritual calculus that does not always require threats of damnation (though these are present) and instead defines deprivation and loss in this world "as a means to the measureless prize of eternal life. ${ }^{~}{ }^{60}$ Or as Roger Sales acerbically puts it, there is "the lie 
that there will be pie in the sky when you die." ${ }^{\circ 1}$ What such responses risk overlooking in their attention to transcendental impulses is the fact that these were historically and politically situated narratives, with calculated social designs, even if they did not always cast their insistence upon popular devotion in explicitly antiradical terms.

When they were first serialized from 1809 through 1816 in the Christian Guardian, the narratives appeared under the signature "Simplex" in a department called "The Poor Man's Friend" as a calculated response to William Cobbett (known as "the poor man's friend") and a rising tide of popular discontent in the later years of the Napoleonic wars. ${ }^{62}$ Just as the Religious Tract Society tended to sort audiences and topics that Hannah More orchestrated within comprehensive tract series, so the periodical publication of Richmond's narratives involved a division of labor, with matters of topical reference, political argument, and commercial enterprise assigned to the magazine frame. Launched in Bristol in 1802 as a "Theological Miscellany," the Christian Guardian became more explicitly political through the renewal of war with France and the revival of domestic radicalism. "The Poor Man's Friend" first appeared in 1809 as part of a new series that decisively addressed the popular radical threat from below. The magazine encouraged laborers to prefer church and scripture to the alehouse and such "bad books and newspapers" as Cobbett's Political Register and The Examiner of John and Leigh Hunt: "Mind religion, not politics. If any thing should appear wrong in the Government, leave it alone; it is not your business to attempt a Reform in Parliament, if it be necessary, leave it to those who are of consequence in the state." ${ }^{33}$ Contentment was recommended on the doctrinal grounds that "a complaining Christian is a disgrace to Christianity," and ordinary subjects were reminded that even pious devotion should not interfere with diligent labor. "There is a time to hear sermons, and a time to provide for our families. ${ }^{" 64}$

This last maxim was calculated to soften lingering elite suspicion of evangelical fervor, and it is clear throughout the Christian Guardian that vernacular address was shaped as much by the effort to enlist subsidies for tract publication as it was by a desire to reach disaffected subjects, for whom the monthly magazine was an unpromisingly expensive format. An 1813 letter "On the Conduct of Manufactories" urged factory owners to sponsor Sunday schools and supply their laborers with improving evangelical tracts, and footnotes promoted the catalog of the Religious Tract Society as well as reprinted Cheap Repository tales. ${ }^{65}$ "A Young Pastor's Account of the Rude Ignorance, Immorality, Dissent, Disloyalty, and Superstition of His Parish" vividly related how a predecessor's neglect encouraged popular immorality and discontent "of the grossest democratical nature." A sequel, "The Steps Taken by a Young Pastor Towards the Reformation of his Parish," sketched an exemplary program of putting down public houses and village festivals, erecting stocks and 
prisons, and establishing Sunday schools and tract societies for the poor. ${ }^{66}$ In the "awful crisis" of 1819, "An Englishwoman's Address to Her Countrymen on the Present Times" enlisted women to combat "rebellion and infidelity" by forbidding "irreligious and immoral publications" among their servants, and by supporting the neighborhood distribution of "religious and loyal" publications. ${ }^{67}$ Through the alarming first wave of unstamped radical weeklies inaugurated by Cobbett's November 1816 address "To the Journeymen and Labourers," the Christian Guardian reinforced its publication of a sample pious tract, A Word in Season; or, A Dialogue on the Present Times, with a department called "Loyal Tracts," which offered wholesale discounts on a range of titles, including such landmark 1790s loyalist association pamphlets as More's Village Politics and William Paley's Reasons for Contentment. The rationale for subsidized distribution also recalled the 1790s:

The best antidote to the poisonous publications which have been so industriously circulated throughout the kingdom, is a series of Tracts containing sound arguments and loyal sentiments, well circulated among the lower orders of society; thus making the press its own corrector, and not only preserving the liberty of the press, but promoting the liberty of the people. It becomes every Christian, who must of course, or ought to be, a true loyal subject, to do all he can to counteract by these simple and legal methods, the prevailing disregard for all authority, and the dreadful extension of irreligion and profaneness. ${ }^{68}$

It was within this aggressive promotional framework that the tales collected in Annals of the Poor made their first periodical appearance, in part as presentation texts for elite donors and middle-class activists, although the Christian Guardian was listed among the "good books" factory owners could make available to workers. ${ }^{69}$ This magazine campaign against popular radicalism is crucial to understanding the narrative design of Richmond's tracts. He could afford the attitude of contemplative ease struck by his framing landscape meditations, as well as the otherworldly movement of his deathbed scenes, in part because the more strenuous and coercive portion of moral reform was being done just outside the boundaries of narration, in the Christian Guardian magazine and through the institutional machinery of the Religious Tract Society.

This kind of contextualization does not in itself embarrass recent recuperations of The Young Cottager and The Dairyman's Daughter, which already had a long nineteenth-century history of being activated beyond the immediate circumstances of their first production. Again, what is being discovered in these narratives today is not simply enduring truth, but a distinctive evangelical commitment to the wars of truth in a world always pitching toward human corruption. For all their attendant fascination with Victorian handicraft and the one-room schoolhouse, the language in which contemporary Christian websites present the recovered literature of moral reform is the language of 
ongoing enterprise rather than nostalgic retrospection: Grace and Truth offers "character-building books from past centuries for families pursuing righteousness today." 70 The promotion of 1790 s loyalist association tracts by the Christian Guardian in 1817 reminds us that Hannah More herself re-presented her work for later episodes of crisis, so that Village Politics came out again in 1819 as The Village Disputants; or, A Conversation on the Present Times, with updated treatments of postwar debt and taxation. ${ }^{71}$ This accommodation to shifting circumstance over time, without a clear developmental framework, is consistent with an evangelical sense of social degeneration as the enduring counterpart to ongoing moral reform. If More did not share the deep traditionalism we associate (perhaps mistakenly) with Edmund Burke, she answered a perceived radical spirit of utopian perfectibility with a skeptical tendency to make this world a scene of permanent correction. She described the Cheap Repository as contributing "to that great work of reformation, which will, I trust, unless a total subversion of manners should take place, be always carrying on in the world; but which the joint concurrence of the wisdom of ages will find it hard to accomplish." 72

Along with methods of subsidized provision and disciplinary address, Legh Richmond shared with Hannah More this commitment to a reformist enterprise that never fully accomplished the work of writing, reading, publishing, and teaching. And it was this premise-turning upon an acute evangelical theology of human impairment and resisting any simply "conservative" politics of retrospection-that made his own narratives of moral reform more worldly and material than they were transcendental, and pertinent today in ways that are difficult to conceive for other strands of romanticperiod conservatism. (What contemporary claim might there be for the anti-Jacobin novel's burlesque distortions of William Godwin and Mary Wollstonecraft, or for Samuel Taylor Coleridge's worrying about "the plebification of knowledge" under mass education? $)^{73}$ There was certainly room in Richmond's writing for the nostalgia that lurked in reassuring visions of cottage virtue and agricultural plenitude. But Annals of the Poor are more surely underwritten by the darker shades of a fallen world and corrupt human nature that enjoin ongoing redemptive social work. In The Young Cottager's treatment of the conversion and early death of the Sunday school student "Jane S-" (in life, Jane Squib of Brading) this is evident in a crucial episode of churchyard pedagogy. The material implications of this phase of the narrative serve to complicate an interpretive approach that would focus on the transcendental movement of Jane's deathbed transformation into a pious moral example.

Within a rural geography saturated by spiritual instruction, Richmond's churchyard brings nature and culture together in a privileged site for popular instruction. The procedures of a churchyard pedagogy turn out to be 
distinct from the more elevated Christian emblematic conventions associated with his own framing reflections and landscape meditations, where for example "the shepherd and his flock" offer an "illustration of the nature and character of the Redeemer's kingdom" and "the very flowers and leaves of the garden and field are emblematical of higher things." ${ }^{, 74}$ There is a suggestion that "the beauties of created nature" spreading out beyond the church afford opportunities for "useful instruction" among the village youth (155), yet this conceit actually triggers further authorial reflection, and a series of metonymic associations that proceed first along the distant prospects of "a large river" and "a hill of peculiarly beautiful form," then on down through the nearer "intermixture of houses with gardens, orchards, and trees," until the mind comes to rest on "my own little shrubberies and flowerbeds," and the conclusion that, "had the sweet Psalmist of Israel sat in this spot, he would have glorified God the Creator by descanting on these his handy works" (155-56). If this movement recalls Coleridge's conversation poems, reinforcing Gary Kelly's sense of an evangelical appropriation of romanticism, it is worth considering that eighteenth-century antecedents of the Christian Guardian developed a popular Christian magazine verse whose rendering of nature anticipated romantic strategies. ${ }^{75}$ In any case, Richmond overwhelmingly assigns such devices to the disposition of the author, while popular pedagogy comes to rest more narrowly within the confines of "my own little garden" and the adjacent churchyard.

The fact that aggressive social work fell just outside the boundaries of narration, in the frame of magazine serialization and Religious Tract Society enterprise, released Richmond from Hannah More's brand of compulsive self-promotion and self-reference, which made it clear that popular piety and contentment were an evangelical production. ${ }^{76}$ Yet there was a calculated misrepresentation about the way The Young Cottager did not disclose the business of moral reform. Within a tract that became a Sunday school set text, the one group of children gathered at an idealized rural churchyard offer a sentimental synecdoche for the aggressive procedures by which a national network of evangelical schools made a limited dispensation of literacy available to English subjects within a managed print economy of charitable provision. Jane was among the children Richmond "invited and regularly instructed every Saturday afternoon" at his rectory garden:

On the summer evenings I frequently used to assemble this little group out of doors in my garden, sitting under the shade of some trees, which protected us from the heat of the sun. From hence a scene appeared, which rendered my occupation the more interesting. For adjoining the spot where we sat, and only separated from us by a fence, was the churchyard, surrounded with beautiful prospects in every direction.

There lay the mortal remains of thousands, who from age to age, in their different generations, had been successively committed to the grave, "earth to earth, 
ashes to ashes, dust to dust." Here the once famed ancestors of the rich, and the less known forefathers of the poor, lay mingling their dust together, and alike waiting the resurrection from the dead. (152-53)

Edmund Burke seems present here, as in other landscapes by Richmond, in the way spiritual impulses are organized and materialized through an interred ancestral community. ${ }^{77}$ Heather Glen has observed that "death . . was the central theme of evangelical pedagogy," and it is crucial to the tract's purposes that Jane appears even in life, as a subject of instruction, within the social and religious framework that will later receive her remains. ${ }^{78}$ This episode also deliberately engages the poem that gave Annals of the Poor its title and epigraph, Thomas Gray's "Elegy Written in a Country Churchyard," which is at once everywhere and nowhere in the volume. With Gray in mind, it is clear that the development of ancestral community-literally the ground beneath the children's feet—as an almost apocalyptic precondition for ensuing scenes of instruction betrays a crucial evangelical revision. In his study of English canon formation, John Guillory accounts for the "generic anachronism" of Gray's pastoral by identifying the "Elegy" with "the last moment at which literary culture can sustain a discourse of polite letters in the vernacular without establishing this discourse in the schools." ${ }^{\prime 7}$ By appropriating Gray to evangelical conversion narrative, Annals of the Poor marks the pivot to a very different dispensation for literacy within what remains to this day an evangelical alternative or countercanon. Gray's sense of literacy as gulf between rustic "swain" and poetic speaker- "Approach and read (for thou can'st read)"-gives way to a sentimental churchyard transfiguration of the institutional procedures that work to eliminate such a gulf by incorporating new subjects into a national discipline of devotional literacy. ${ }^{80}$

If this evangelical revision of Burke's patrimony and Gray's pastoral represents a calculated appropriation of inherited authority, the reference to the Anglican Order for the Burial of the Dead ("earth to earth, ashes to ashes, dust to dust") is arguably more ambiguous. There is something less here than a direct assertion of the author's ministry, perhaps confirming Kyle Roberts's suggestion that, by comparison with Hannah More, Richmond offers a spiritual dispensation that is more widely distributed and less strictly hierarchical, so that a dairyman's daughter can be a figure of "emulation for all classes." $\$ 1$ Just as humanity proceeds along two paths in the tract's evangelical vision, with "mortal remains" disintegrating into earth while soul anticipates rebirth, so the allusion to the Book of Common Prayer seems to move in two directions, establishing the clerical foundations for the Reverend Legh Richmond's literary and instructional authority, even as it risks invoking that authority in an ecstatic service that dissolves power and language itself into the elemental form of ashes and dust. Yet the apocalyptic apprehension of a spiritual rebirth 
that will dissolve social hierarchy ("alike waiting") turns out to be fleeting, as the narrative pursues a more worldly course. The same contraction of perspective that brought Richmond back from expansive spiritualized prospects to the churchyard as scene of instruction soon finds him reconstituting the word in the more durable form of a gravestone inscription, as he proceeds from ancestral memory and anticipated resurrection to the present demands of evangelical pedagogy.

In describing his methods as a teacher, Richmond acknowledges that his charges "used to read, repeat catechisms, psalms, hymns, and portions of Scripture" (152). But The Young Cottager privileges a more immanent and unmediated form of instruction, specific to the setting:

I had not far to look for subjects of warning and exhortation suitable to my little flocks of lambs that I was feeding. I could point to the heaving sods that marked the different graves and separated them from each other, and tell my pupils that, young as they were, none of them were too young to die: and that probably more than half of the bodies which were buried there, were those of little children. I hence took occasion to speak of the nature and value of a soul, and to ask them where they expected their souls to go when they departed hence and were no more seen on earth....

Sometimes I sent the children to the various stones which stood at the head of the graves, and bid them learn the epitaphs inscribed upon them. I took pleasure in seeing the little ones thus dispersed in the churchyard, each committing to memory a few verses written in commemoration of the departed. They would soon accomplish the desired object, and eagerly return to me ambitious to repeat their task.

Thus my churchyard became a book of instruction, and every grave-stone a leaf of edification for my young disciples. (153-54)

Here a text destined to enter the Sunday school curriculum seems to disclaim the need for such texts. The narrative sleight of hand recalls even as it reverses Hannah More's habit of disclosing that found objects of natural rural piety, for example the Shepherd of Salisbury Plain, were actually the product of Cheap Repository narration. For Richmond, textual means of "warning and admonition" sufficient to the formation of converted subjects were already present in the world, as a transmission from mingled generations "successively committed to the grave."

Yet for all the appeal of the monitory gravestone as inherited and embedded script, Richmond turns out to be unwilling to accept the available "leaf of edification" in the imperfect form by which it has come down to him "from age to age" in an idealized rural community. This is clear later in the narrativeafter a conversion that Jane herself credits to "your talking about the graves in the churchyard" (169), but before her sentimentally rendered death-in an episode where Richmond passes through the same churchyard on his way to her sickroom. Arrested in his progress by the epitaph that contributed signally 
to her conversion, he takes a master's lesson in the commemorative forms of instruction. The tract exceeds its boundaries at this point in the sense that it invokes an evangelical campaign, waged in the pages of the Christian Guardian magazine, to suppress a debased popular appetite for comic and irreverent epitaphs through a coercive system of renewed clerical surveillance:

I was struck with the reflection of the important consequences which might result from a more frequent and judicious attention to the inscriptions placed in our burying-grounds, as memorials of the departed. ... I have often lamented, when indulging a contemplation among the graves, that some of the inscriptions were coarse and ridiculous; others, absurdly flattering; many expressive of sentiment at variance with the true principles of the word of God; not a few, barren and unaccompanied with a single word of useful instruction to the reader. Thus a very important opportunity of conveying scriptural admonition is lost. I wish that every gravestone might not only record the name of our deceased friends, but also proclaim the name of Jesus, as the only name given under heaven whereby men can be saved. Perhaps, if the ministers of religion were to interest themselves in this matter, and accustom their people to consult them as to the nature of the monumental inscriptions which they wish to introduce into churches and churchyards, a gradual improvement would take place in this respect. What is offensive, useless, or erroneous, would no longer find admittance, and a succession of valuable warning and consolation to the living would perpetuate the memory of the dead.

... I therefore offer this suggestion to my reverend brethren, that as no monument or stone can be placed in a church or churchyard without their express consent or approbation, whether one condition of that consent being granted, should not be a previous inspection and approval of every inscription which may be so placed within the precincts of the sanctuary. $(173-75)^{82}$

Within a narrative that culminates in Jane's instructive death, and that later made Jane Squibb's grave an object of evangelical pilgrimage for generations of British and American visitors, this reassertion of clerical oversight through the management of public commemoration indicates the limits of Richmond's commitment to the acculturating value of inherited scripts. ${ }^{83}$ Far from marking the terminus of present enterprise in this world, the act of memorializing the dead is itself subject to revision and hierarchical control. An epitaph assumes its appropriate monitory form, not as ancestral inheritance, but rather as something projected forward to a conditionally receding future state in this world, where "gradual improvement" will yield a reclaimed populace accustomed to evangelical discipline.

The contraction of address here to "my reverend brethren" confirms a renewed sense of clerical purpose occasioned by the management of "coarse and ridiculous" popular sensibilities. This ministerial control over inscription qualifies any egalitarian sense there may be about the young cottager's moral authority. When Jane does speak again, her spectral voice issues through Richmond's own transcription of the epitaphs she learned under his graveyard 
tutelage: "Little Jane, though dead, yet shall speak. While I transcribe the lines, I can powerfully imagine that I hear her voice repeating them" (157-58). In this way, the open pedagogy suggested by "a kind of free conversational examination" (152) among his students finds its way back into the familiar strictures of catechism, where church hierarchy contains popular expression within the frame of acquired and reiterated utterance. ${ }^{84}$ The limits of popular aspiration in an economy of evangelical provision were already vividly registered in the way Richmond's students returned to him from their churchyard "book of instruction" eager "to repeat their task." A language of evangelical conversion all comes back, as Jane acknowledges, to "your talking."

What is interesting about this narrative strategy of containment is that it proves compatible with a more disseminatory publishing history of revision and supplementation. The importance of managing commemoration as an ongoing and worldly (rather than retrospective or transcendental) enterprise was confirmed when Richmond and his later editors and publishers went about circulating The Young Cottager and the other narratives of "The Poor Man's Friend" in ways that extended the resourcefulness of the periodical series out through any number of revised versions. Again, the climactic death of young Jane should not obscure the fact that already in its first serial appearance the tract resisted closure through a strategy of commemorative revision. The Christian Guardian narrative culminated in May 1814, in a sixth and last part, not with Jane's death, nor with her internment in an unadorned grave, but rather with a series of further interventions in her memory. A yew tree that Richmond planted "close by the head of her grave" proves "a frail and short lived monument," but its death leads him to hope that "perhaps this narrative may be permitted to transmit her memory to other generations, when the hand and heart of the writer shall be cold in the dust." ${ }^{85}$ This morbid rendering of his own labor then leads Richmond back to the sense of an audience composed of "my clerical brethren," as he sympathizes with other Christian ministers who have perhaps lost a lovingly reared "flower" to untimely "blight." A final paragraph then reactivates churchyard pedagogy by encouraging other ministers to apply to their own case an epitaph "inscribed on a gravestone" near where Jane lies buried:

\footnotetext{
This lovely bud, so young and fair,

Call'd hence by early doom,

Just came to show how sweet a flower

In Paradise would bloom. ${ }^{86}$
}

As a closing device, this epitaphic double substitution-another epitaph for that of Jane, other ministers for Richmond-is calculated to extend the reach of the narrative to other figures and other lives. In this sense, even before the appearance of later versions of the tract, the character Jane was 
launched into the world as a version of herself. And because this final part of The Young Cottager closed fortuitously upon a promotional notice in the Christian Guardian for the first appearance of Annals of the Poor, the epitaph was followed by a pseudonymous signature ("Simplex") now made redundant by a footnote revealing the Reverend Legh Richmond's authorship and advertising the new volume, "neatly printed in $12 \mathrm{mo} .{ }^{.87}$ Later, in Annals of the Poor and in the publication of The Young Cottager as number 151 in the Religious Tract Society's first series, the revised narrative was extended through a second epitaph that vividly enacted the ongoing evangelical work of commemoration within and beyond the printed page. A further paragraph now explained how "a tribute of affection has been paid to the memory of the Young Cottager, by raising a subscription, and putting up a gravestone," whose verses honor Richmond and his publications no less than the deceased person since they identify her as "JANE 'the YOUNG COTTAGER'" and quote Gray's elegy on "The short and simple annals of the poor!" (226). ${ }^{88}$

But we are still not done. The success of the Religious Tract Society inspired similar operations in the United States, including the New York Religious Tract Society (1812) and the New England Tract Society (1814), which joined to form the American Tract Society in 1825 and filled out their publication lists with material drawn from British counterparts. ${ }^{89}$ (Twenty-first-century Grace and Truth editions of Richmond and Hannah More derive from these sources.) After Richmond's death there appeared in America enterprising editions of The Young Cottager that extended his own serial pattern of supplementation and revision, and confirmed the tendency for printed text to supersede interred body and commemorated life, by appending to Jane's narrative a further memorial to the author under the title "Visit to the Graves of the Dairyman's Daughter and the Young Cottager, July, 1823." This "Visit" related not a single event but a series of pilgrimages by friends and acquaintances, converging on a reprinted pastoral letter sent by Richmond to his parish at Turvey recounting his own sentimental reunion with hundreds of parishioners on the Isle of Wight in September 1822 for the dedication of Jane's gravestone. At this point his tracts had already become evangelical bestsellers:

It was a time of great feeling, and a tribute of much love was paid to the graves of the deceased. Some were there weeping with gratitude in having been brought to God through the reading of those very Tracts. The father and mother of Little Jane were at the grave while the stone was putting up. We then went to the house where she died, and the young Cottager's Tract was given to every one that came. ${ }^{90}$

In life and after death, the rigors of conversion and commemoration extend through this process by which printed tracts pass from hand to hand, endlessly converting souls and conscripting bodies. The appended "Visit" also recorded the astonishing circulation of four million copies of The Young Cottager by 
1828, and the "multitudes of instances in which [the] Tract has been blessed in the conversion of souls." 91

To this day, the social work of evangelical moral reform continues to unfold within an uneven dialectic of imperfect commemoration and ongoing inscription and revision. In coming to terms with the present American revival of a British romantic-period evangelical revival, it is worth considering that such recuperations operate productively, as a forward-looking extension of the work of Christian repair, and cannot simply be dismissed as evidence of a misguided nostalgia for a past that even More and Richmond did not take for granted. In recommending its electronic edition of The Dairyman's Daughter as an antidote to infidelity in dark times, the "Sound Doctrine Library" strikes a note of revival that recalls Richmond's habit of distributing his tracts beside gravestones commemorating his own transfiguration of persons into tracts:

This classic of the faith was sold in great numbers when it was first published in 1810 . It has continued ever since to have its inspiring effect on those who know the love of the Lord Jesus Christ in their hearts. And how important it is, in these dark days of widespread apostasy, that this classic might yet prove useful again in awakening the hearts of others, like Elizabeth Wallbridge, the dairyman's daughter, whom the Lord called to bear witness to Him in so wonderful a way, before her early death. ${ }^{92}$

There are certainly striking historical oversights about the way Richmond and More are being recovered as classics for present-day readers. Yet such oversights themselves serve notice that our own historicist interest in reconstructing the particular conditions for literary production must remain open to the way texts can be promiscuously reactivated under other circumstances.

In a searching and thoughtful reflection on historical method, Heather Glen introduces her recent study of Charlotte Brontë by calling our attention to the way the strange immediacy of Brontë's fiction encourages "an intensity of identification that threatens to overwhelm the critical faculties" as well as the sense of historical difference. This distinctive literature requires a distinctive historical method: "We need less to reconstruct a 'history' that will make these familiar works seem strange than to read the 'history' we think we know through the prism of that 'strangeness' which readers find in them." 93 Glen accomplishes this brilliantly by allowing the novels to point toward various early nineteenth-century phenomena, ranging from gift books and sanitary reform to the Great Exhibition. Jane Eyre points, among other things, to early nineteenth-century evangelical education, whose rigors make "Jane's story begin to appear less as the work of a 'morbid fancy' than as an emphatic invocation of some of the key terms and concepts of a well-known contemporary discourse. ${ }^{" 94}$ To excavate that discourse, Glen turns to Legh Richmond and the posthumous volume Domestic Portraiture (1833), which reprints notes he was in the habit of leaving to his children admonishing 
them to consider their own sinful condition and the prospect of eternal damnation. "Has the affecting thought, 'I must live for ever in heaven or hell,' suitably impressed your mind?" 95 The gesture recalls the harrowing graveyard pedagogy of The Young Cottager. "I could point to the heaving sods that marked the different graves and separated them from each other, and tell my pupils that, young as they were, none of them were too young to die." What Being Virtuous Women and Grace and Truth Books remind us, as historicist critics and as secular readers, is that there are still today other readers of Legh Richmond, and no doubt Brontë as well, for whom such an attitude does not involve a great sense of historical distance. Our understanding of canon formation and literary recovery should attend more often than it does to other canons and other recoveries. Evangelicals are certainly not alone in finding their way to a "classic" literature of the nineteenth century. When I first discovered the online presence of Hannah More and Legh Richmond, I was reminded that well before there were scholarly online editions of Percy Bysshe Shelley's "The Necessity of Atheism" my students read it through the "Historical Library" of the Secular Web at infidels.org. ${ }^{96}$ I have argued elsewhere against accounts of Hannah More as a progressive or even revolutionary figure, and endorsed instead a view of her work as an enterprising and dynamic yet still disciplinary response to the threat of revolution and Enlightenment secularism. ${ }^{97}$ We can extend a similar consideration to contemporary evangelical recuperations of Legh Richmond and Hannah More that strangely shadow our own revisions of the romantic literary canon.

\section{Notes}

For their insightful feedback on earlier versions of this article, I want to thank Theresa Kelley, Nigel Leask, Alex Benchimol, John Barrell, and Celest Woo, as well as members of the Centre for Eighteenth Century Studies at the University of York and the English Literature department at the University of Glasgow. I am grateful too for thoughtful suggestions for revision from Ian Duncan and the editorial board of Representations.

1. Hardbound editions include Woodstock Books' Strictures on Female Education (Oxford, 1995) and Village Politics 1793, with The Shepherd of Salisbury Plain (Oxford, 1995), and Pickering and Chatto's Selected Writings of Hannah More, ed. Robert Hole (London, 1996). Paperback editions include Broadview's Coelebs in Search of a Wife, ed. Patricia Demers (Peterborough, ON, 2007), and Trent Editions' Tales for the Common People and Other Cheap Repository Tracts, ed. Clare MacDonald Shaw (Nottingham, 2002).

2. Hannah More, Practical Piety, Grace Gems, http:/ / www.gracegems.org/Books2/ More.htm; Hannah More, Grace to the Humble, Including the Stories of Tom White 
the Postboy and Charles Jones the Footman (Sand Springs, OK, 2003); and Hannah More, The Two Wealthy Farmers (Sand Springs, OK, 2004).

3. More, The Two Wealthy Farmers, verso of title page. The Cheap Repository was a series of narrative, ballad, and allegorical tracts published by Hannah More from 1795 through 1798, in editions subsidized by elites for ordinary readers, as part of the first wave of a loyalist response to the threat of the French Revolution and domestic radical protest.

4. "Radio Bible \& Book Room Catalog," Radio Missions, http:/ /www.radiomissions. org/catalog/family.shtml, and "Preferred Booklist," Utmost Enterprises, http:// www.utmost-way.com/preflistfrm.htm.

5. For Christian homeschooling, see John Micklethwait and Adrian Wooldridge, The Right Nation: Conservative Power in America (New York, 2004), 189-94; and Michelle Goldberg, Kingdom Coming: The Rise of Christian Nationalism (New York, 2006), 94-95, 172-73.

6. George M. Marsden, Fundamentalism and American Culture, 2nd ed. (Oxford, 2006), 250-51.

7. For the early nineteenth-century distribution of British tract literature by American tract societies, see John Wolffe, The Expansion of Evangelicalism: The Age of Wilberforce, More, Chalmers and Finney (Downers Grove, IL, 2007), 168-69.

8. Legh Richmond, The Dairyman's Daughter (Sand Springs, OK, 2005); and Legh Richmond, The Young Cottager (Sand Springs, OK, 2002).

9. Gary Kelly, "Romantic Evangelicalism: Religion, Social Conflict, and Literary Form in Legh Richmond's Annals of the Poor," English Studies in Canada 16 (1990): 165-88; and Roger Sales, English Literature in History, 1780-1830: Pastoral and Politics (New York, 1983), 23-27.

10. Legh Richmond, The Negro Servant, Documenting the American South, http:// docsouth.unc.edu/neh/richmond/menu.html.

11. Legh Richmond, The Dairyman's Daughter, sounddoctrine.net, http://www. sounddoctrine.net/LIBRARY/Misc\%20Articles/Classic_True_Story.htm; and Legh Richmond, The Dairyman's Daughter, ed. Amber Moeller, Being Virtuous Women, http://www.beingvirtuouswomen.com/cms/bvw_shelf/our_ebooks/dairymans_ daughter/.

12. “About BVW," Being Virtuous Women, http:/ /www.beingvirtuouswomen.com/ cms/about_bvw/.

13. The link to "Ladies Against Feminism" can be found at "Feminine Interests," Being Virtuous Women, http://www.beingvirtuouswomen.com/cms/favorite_ links/feminine_interests.php.

14. "Handbasket," Being Virtuous Women, http:/ /www.beingvirtuouswomen.com/ cms/homemaking/handbasket/.

15. “About BVW," Being Virtuous Women.

16. Robert Glenn Howard, "Enacting a Virtual 'Ekklesia': Online Christian Fundamentalism as Vernacular Religion," New Media and Society 11 (2009): 15-16.

17. "About BVW," Being Virtuous Women.

18. See "Husband/Father 'Covering' His Wife/Daughter?” Being Virtuous Women, http://www.beingvirtuouswomen.com/cms/about_bvw/quill_penfaq/husband father_covering_his_wifedaughter.php; and "Biblical Vision for Daughters over 20?” Being Virtuous Women, http://www.beingvirtuouswomen.com/cms/about_ bvw/quill_penfaq/biblical_vision_for_daughters_over_20.php. 
19. “A Merry Future Homemaker-Part Two," Being Virtuous Women, http:// www.beingvirtuouswomen.com/cms/bvw_shelf/musings/a_merry_future_ homemaker_part_two.php.

20. "Privacy Policy," Being Virtuous Women, http://www.beingvirtuouswomen.com/ cms/about_bvw/privacy_policy/.

21. "Feminine Interests," Being Virtuous Women. There is a system of asterisks to identify specifically Christian resources.

22. "Recommended Books," Being Virtuous Women, http://www.beingvirtuous women.com/cms/bvw_shelf/bookworm_corner/recommended_books.php.

23. "Quill Pen-FAQ," Being Virtuous Women, http://www.beingvirtuouswomen. com/cms/about_bvw/quill_penfaq/.

24. This tension, often hinging on the question of whether America is a new Zion or Babylon, is particularly evident in studies of Protestant fundamentalism since the 1920s. See Robert Wuthnow, The Restructuring of American Religion: Society and Faith Since World War II (Princeton, 1990), 195-96; and Joel A. Carpenter, Revive Us Again: The Reawakening of American Fundamentalism (New York, 1997), 11-12. For the view that "evangelicalism is especially vigorous when it is closely connected with the cultural mainstream yet maintains a sense of being culturally embattled against it," see Marsden, Fundamentalism and American Culture, 255.

25. The phrase is from Marsden, Fundamentalism and American Culture, 4. For a survey of the conflict between fundamentalism and modernism, see Mark A. Noll, A History of Christianity in the United States and Canada (Grand Rapids, MI, 1992), 373-86.

26. Carla Pasquinelli, "Fundamentalisms," Constellations 5 (1998): 10, 14.

27. Ibid., 14-16, 17. See S. N. Eisenstadt, Fundamentalism, Sectarianism, and Revolution: The Jacobin Dimension of Modernity (Cambridge, 1999), for another version of the argument "that contemporary fundamentalist movements are thoroughly modern movements, albeit promulgating anti-modern or anti-Enlightenment ideologies" (1).

28. Marsden, Fundamentalism and American Culture, 231.

29. See for example Carpenter, Revive Us Again, 234-35; and Douglas Carl Abrams, Selling the Old-Time Religion: American Fundamentalists and Mass Culture, 1920 1940 (Athens, GA, 2001), 59-60. For shifting alignments of evangelicalism and fundamentalism since the 1920s and the current "fundamentalistic evangelicalism," see Marsden, Fundamentalism and American Culture, 233-36.

30. The phrase "pilgrims in cyberspace" is from Quentin J. Schultze, "Following Pilgrims into Cyberspace," in Understanding Evangelical Media: The Changing Face of Christian Communication, ed. Quentin J. Schultze and Robert H. Woods (Downers Grove, IL, 2008), 148. For evangelical radio in the United States, see Tona J. Hangen, Redeeming the Dial: Radio, Religion, and Popular Culture in America (Chapel Hill, 2002). For television, see Wuthnow, Restructuring of American Religion, 194-98; and Michele Rosenthal, American Protestants and TV in the 1950s: Responses to a New Medium (New York, 2007).

31. Martin E. Marty, "The Revival of Evangelicalism and Southern Religion," in Varieties of Southern Evangelicalism, ed. David E. Harrell Jr. (Macon, GA, 1981), 9; and Carpenter, Revive Us Again, 234-35. Carpenter cites Marty's formulation.

32. Carpenter, Revive Us Again, 235. For Whitefield as "the first modern religious celebrity" and a progenitor of evangelical modernity, who "adapted the rhetoric 
and techniques of the secular marketplace," see Rosenthal, American Protestants and TV in the 1950s, 10.

33. Boyd Hilton, The Age of Atonement: The Influence of Evangelicalism on Social and Economic Thought, 1785-1865 (Oxford, 1988), 3.

34. Darrin M. McMahon, Enemies of the Enlightenment: The French Counter-Enlightenment and the Making of Modernity (Oxford, 2001), 14-15. I draw on McMahon in my own study of counterrevolutionary culture in Britain, Writing Against Revolution: Literary Conservatism in Britain, 1790-1830 (Cambridge, 2007).

35. See Marsden, Fundamentalism and American Culture, 255. There is a connection again with Pasquinelli's case: the resilience of Protestant fundamentalism in America has been taken to challenge dominant models of a secularizing modernity. See Carpenter, Revive Us Again, 234.

36. Hannah More, The Works of Hannah More, 8 vols. (London, 1801), 5:vii-viii.

37. François Furet, Interpreting the French Revolution (Cambridge, 1981).

38. Joanna Innes, "Politics and Morals: The Reformation of Manners in Later Eighteenth-Century England," in The Transformation of Political Culture: England and Germany in the Late Eighteenth Century, ed. Eckhart Hellmuth (Oxford, 1990), $60,66-67,75-85$.

39. Grace and Truth Books, Spring-Summer 2005 Catalogue, 8, in a description of Elyse Fitzpatrick and Carol Cornish, Women Helping Women (Eugene, OR, 1997). The current online catalog revises the language, promising "a gold-mine of instruction on issues that arise among women with not an ounce of psychobabble." See http://www.graceandtruthbooks.com/product/women-helping-women -a-biblical-guide-to-the-major-issues-women-face.

40. A. G. Newell, "Studies in Evangelical Popular Prose Literature: Its Rise and Decline" (PhD Diss., Liverpool University, 1976), 331-91; and The Blackwell Dictionary of Evangelical Biography, 1730-1860, ed. D. M. Lewis (Oxford, 1995), s.v. "Richmond, Legh," by A. G. Newell.

41. Hilton, The Age of Atonement, 16-19.

42. Robert Glenn Howard, "On-line Ethnography of Dispensationalist Discourse: Revealed Versus Negotiated Truth," Religion on the Internet 8 (2000): 228. Carpenter provides a useful summary of millenarian views in the United States, including modern premillennialism and dispensationalism, in an appendix to Revive Us Again, 247-49.

43. Kathryn Teresa Long, The Revival of 1857-58: Interpreting an American Religious Awakening (New York, 1998), 112.

44. Marsden, Fundamentalism and American Culture, 62-66.

45. For romantic historicism as a challenge to universal standards, see Ted Underwood, "Stories of Parallel Lives and the Status Anxieties of Contemporary Historicism," Representations 85 (Winter 2004): 5; and Ted Underwood, "Romantic Historicism and the Afterlife," PMLA 117 (2002): 239; for "dated specificity" see James Chandler, England in 1819: The Politics of Literary Culture and the Case of Romantic Historicism (Chicago, 1998), xiii, xvi, 5.

46. Tracts drawn from these authors are listed in "Catalogue of the Publications of the Society," in The Twenty-Fifth Annual Report of the Religious Tract Society (London, 1824), 93-97.

47. Marsden, Fundamentalism and American Culture, and Carpenter, Revive Us Again, 248-49. For an intriguing argument for the romantic origins of dispensationalism and modern fundamentalism, see Ted Underwood, "If Romantic Historicism 
Shaped Modern Fundamentalism, Would that Count as Secularization?" European Romantic Review 21 (2010): 327-43.

48. Chandler, England in 1819, xv.

49. My sources for Richmond's life are The Blackwell Dictionary of Evangelical Biography, s.v. "Richmond, Legh"; T. S. Grimshawe, A Memoir of the Rev. Legh Richmond, 7 th American ed. (New York, 1844); and Oxford Dictionary of National Biography, ed. H. C. G. Matthew and Brian Harrison (Oxford, 2004), s.v. "Richmond, Legh (1771-1827),” by G. F. W. Munby, rev. Clare L. Taylor; doi:10.1093/ref:odnb/ 23595.

50. The phrase "clergyman in business" is applied to Richmond by R. J. Helmstadter, "The Reverend Andrew Reed (1787-1862): Evangelical Pastor as Entrepreneur," in Religion and Irreligion in Victorian Society, ed. R. W. Davis and R. J. Helmstadter (London, 1992), 10.

51. For this account of More, see Richard Altick, The English Common Reader: A Social History of the Mass Reading Public, 1800-1900 (Chicago, 1957), 76.

52. Helmstadter, "The Reverend Andrew Reed," 9-10.

53. The society figures prominently in Aileen Fyfe's study of Christian popular science, Science and Salvation: Evangelical Popular Science Publication in Victorian Britain (Chicago, 2004).

54. See The Twenty-Fifth Annual Report of the Religious Tract Society, 99-102.

55. Fyfe, Science and Salvation, 265-67.

56. Kyle B. Roberts provides a vivid account of American transmission in "Locating Popular Religion in the Evangelical Tract: The Roots and Routes of The Dairyman's Daughter," Early American Studies 4 (2006): 233-70.

57. Elizabeth Jay, The Religion of the Heart: Anglican Evangelicalism and the NineteenthCentury Novel (Oxford, 1979), 151.

58. Kelly, "Romantic Evangelicalism," 165.

59. Sales, English Literature in History, 23-24.

60. See Sarah Winter, "Curiosity as Didacticism in The Old Curiosity Shop," Novel 34 (2000): 40-41. For a comparison that finds Richmond's narratives "less prescriptive" than those of More, see Roberts, "Locating Popular Religion in the Evangelical Tract," 241.

61. Sales, English Literature in History, 23.

62. Richmond's narratives appeared irregularly in a new series of the magazine (launched in 1809 under the title, The Christian Guardian, and Church of England Magazine), beginning with "The Cottage Conversation" in Christian Guardian 1 (1809): 18-20, and continuing through the final part of the "Recollections of the Dairyman's Daughter" in Christian Guardian 8 (1816): 138-41.

63. Christian Guardian 9 (1817): 168-70, where Cobbett's Register was identified as "C—_s W- P- R- - - The Examiner was "the Ex****er" in Christian Guardian 7 (1815): 84.

64. Christian Guardian 3 (1811): 58-61.

65. Christian Guardian 5 (1813): 47-50.

66. Christian Guardian 7 (1815): 83-88, 194-95.

67. Christian Guardian 11 (1819): 493-95.

68. Christian Guardian 9 (1817): 191.

69. Christian Guardian 5 (1813): 48.

70. Grace and Truth Books, Spring-Summer 2005 Catalogue, 1. The slogan is modified in recent promotional material: "At Grace and Truth, our focal point and 
goal has always been to bring the great, character-building books of past centuries to the attention of this generation of families!" See http://www.graceand truthbooks.com/content/august-sale.

71. For More's participation in the later revival of the Cheap Repository, see Mary Alden Hopkins, Hannah More and Her Circle (New York, 1947), 211-12; and Anne Stott, Hannah More: The First Victorian (Oxford, 2003), 310-11.

72. More, Works of Hannah More, 1:xix-xx. I have discussed More's commitment to permanent reformation in Writing Against Revolution, 86-87.

73. Samuel Taylor Coleridge, On the Constitution of the Church and State, ed. John Colmer, vol. 10, The Collected Works of Samuel Taylor Coleridge (Princeton, 1976), 69-70.

74. Legh Richmond, Annals of the Poor (London, n.d.), 160, 164. Unless otherwise noted, further references to the tracts collected in Annals of the Poor are to this Religious Tract Society edition and will be cited parenthetically. I use this undated early nineteenth-century Religious Tract Society edition, whose title page identifies the society as the publisher, because it gives the text of The Young Cottager in the state it assumed with one paragraph and epitaph (discussed further in the text) added to the end of the serialized Christian Guardian version. Essentially the same text appeared in the similarly undated version that came out in London under the title The Young Cottager; A True Story, as "No. 151" in the society's first series of tracts, "Printed by A. Applegarth . . . For W. Whittemore . . . and Sold by J. Davis ... And J. Nisbet."

75. Robert Mayo, "The Contemporaneity of the 'Lyrical Ballads,'” PMLA 69 (1964): 490n5.

76. For More's self-referentiality, see Patricia Demers, The World of Hannah More (Lexington, KY, 1996), 114; and Gilmartin, Writing Against Revolution, 72-73, 78-80.

77. Burkean terms are more explicit in The Dairyman's Daughter, in a landscape meditation dominated by "a large and venerable mansion" of "Gothic character" that has "descended through a long line of ancestry." See The Dairyman's Daughter, in Annals of the Poor, 13. The sequence was added to Annals of the Poor.

78. Heather Glen, Charlotte Brontë: The Imagination in History (Oxford, 2002), 75.

79. John Guillory, Cultural Capital: The Problem of Literary Canon Formation (Chicago, 1993), 99.

80. Thomas Gray, "Elegy Written in a Country Church-Yard," in Thomas Gray and William Collins: Poetical Works, ed. Roger Lonsdale (Oxford, 1977), 39.

81. Roberts, "Locating Popular Religion in the Evangelical Tract," 241.

82. For this campaign in the magazine, see "On the General Inconsistency of Monumental Inscriptions," Christian Guardian 8 (1805): 51-53.

83. For early tourism see Roberts, "Locating Popular Religion in the Evangelical Tract," 265-66. A current online guide to Jane's grave for Christian visitors can be found at the website England's Christian Heritage, http://www.englands christianheritage.org.uk/index.php?option=com_content\&task=view\&id=30\&I temid $=45$.

84. For the catechism "as a prime means of containing the new literacy" in this period, see Alan Richardson, "The Politics of Childhood: Wordsworth, Blake, and Catechistic Method," ELH 56 (1989): 854.

85. Christian Guardian 6 (1814): 166.

86. Ibid., 167. 87 Ibid. 
88. See also the Religious Tract Society edition, No. 151. The Young Cottager; A True Story (London, n.d.), 48.

89. See Wolffe, Expansion of Evangelicalism, 169.

90. Legh Richmond, The Dairyman's Daughter; The Young Cottager; and The African Servant (New York, n.d.), 176-77. For extracts from Richmond's journal during his 1822 visit to the Isle of Wight and the full text of his pastoral letter, see Grimshawe, A Memoir of the Rev. Legh Richmond, 277-82.

91. Legh Richmond, The Dairyman's Daughter; The Young Cottager; and The African Servant, 175-76.

92. Legh Richmond, The Dairyman's Daughter, sounddoctrine.net.

93. Glen, Charlotte Brontë: The Imagination in History, 1-2.

94. Ibid., 68.

95. Legh Richmond, Domestic Portraiture; or, the Successful Application of Religious Principle in the Education of a Family, Exemplified in the Memoirs of Three of the Deceased Children of the Rev. Legh Richmond (London, 1834), 74. For Brontë's reading of this volume see Glen, Charlotte Brontë: The Imagination in History, 69.

96. Percy Bysshe Shelley, "The Necessity of Atheism," The Secular Web Library, http://www.infidels.org/library/historical/percy_shelley/necessity_of_atheism. html.

97. Gilmartin, Writing Against Revolution, 63-69. 